\title{
Study on the Response of Statice Plants (Limonium sinuatum, L.) to Humic Acid Application

\author{
Hanan E. Ibrahim ${ }^{1}$, Hanan G. H. El-Fadaly ${ }^{1}$, Assem A. M. El-Naggar ${ }^{2}$
}

\begin{abstract}
A pot experiment was conducted on statice (Limonium sinuatum, L.) P. Mill. cv "Sunday Lavander" throughout the two successive growth seasons (2013/2014) and (2014/2015) in El-Zuhrya Botanical Garden, Horticulture Research Institute, Giza, Egypt to study the effect of Humic acid foliar spray $(25 \% \mathrm{w} / \mathrm{v})$ applied at three different doses of application $\left(5.0,10.0,15 \mathrm{~cm}^{3} /\right.$ plant $)$ on vegetative growth, flowering and mineral contents of statice leaves. The foliar spray was applied at either 15 day or 30 day intervals. All statice plants received the recommended NPK fertilization doses except for the unfertilized plants which did not receive any fertilizers. The results indicated that all Humic acid treatments resulted in considerable significant increases on all studied vegetative growth and flowering parameters compared with the control. The results revealed that applying $5 \mathrm{~cm}$ foliar humic acid at 30- day intervals gave the tallest plant height in both seasons. The plants received $15-\mathrm{cm}^{3}$ humic acid at 30-day intervals, gave the highest significant values of leaf number per plant, leaf area, number of branches per plant and fresh and dry weights of leaves compared with the control. While, the highest significant values of stem diameter were observed after treatment with $10 \mathrm{~cm}$ humic at 30-day intervals in both seasons. Whereas, the highest significant values of stem fresh and dry weights were observed after treatment with $15 \mathrm{~cm}^{3}$ humic at 15day intervals. Regarding the effect of Humic acid treatment on flowering parameters. The highest number of stalks per plant was detected after treatment with 15 $\mathrm{cm}^{3}$ humic acid at 15-day. While the highest recorded stalk length values were detected after treatment with $15 \mathrm{~cm}^{3}$ humic acid at 30-day intervals. Whereas, the highest number of florets per flowering stalk and the highest significant values of dry weight of florets per flowering stalk were detected after treatment with $10 \mathrm{~cm}^{3}$ humic acid at 30-day intervals. Also, the results indicated that treatment with $15 \mathrm{~cm}^{3}$ humic acid at 15-day intervals gave the highest significant values of root dry weight. As for the effect of Humic acid application on leaf chlorophyll content and nutrients uptake in leaves, the results revealed that the highest significant values of leaf chlorophyll content and leaf NPK contents were recorded after treatment with $15 \mathrm{~cm}^{3}$ humic acid at 15-day intervals.
\end{abstract}

It can be concluded that Humic acid when applying as foliar spray has a potential effect and can be used for increasing nutrient uptake and availability thus

\footnotetext{
${ }^{1}$ Ornamental Plants and Landscape Gardening Research Dept. Horticultural Research Institute, Giza, Egypt.

${ }^{2}$ Ornamental Plants and Landscape Gardening Research Dept. Antoniades Botanical Garden, Horticultural Research Institute, Alexandria, Egypt.

Received September 4, 2016, Accepted September 27, 2016
}

stimulating growth and flowering characteristics of statice plants cv. "Sunday Lavander".

Key words: Statice plants - cut flower - Humic acidfoliar application.

\section{INTRODUCTION}

Statice is a Mediterranean plant species belongs to the family Plumbaginaceae. It is known for its papery flowers that can be used in dried arrangements. It is cultivated worldwide for its brightly coloured, flat flower clusters that are used in dried and fresh flower arrangements. It's found in Southern of Spain, North of Africa, Canary Islands and even in Palestine. It usually grows up in sandy grounds. Among the many species of the genus Limonium, (Limonium sinuatum, L.) P. Mill. Statice (sea lavender, notch leaf marsh rosemary, sea pink, wavy-leaf sea lavender) is cultivated and recognized as cut flowers crop. These colorful plants are an excellent source of dried flowers. The flowers are borne in clusters and colors include purple, apricot, yellow, pink, and blue. It naturally inhabits mainly coastal areas. Statice is a good choice for seashore use since it is salt tolerant. (Steven, 2008).

Intensive cut flower production demands high levels of fertilization. Improper fertilization may contribute soil, water and environmental pollution. With the rapid increase in population and limited area of cultivation, there is need to improve crop productivity with less effect on the environment. This is only possible with the integration of conventional and non-conventional approaches (Zafar, 2007).

Foliar feeding of nutrients has become an excellent procedure for increasing yield and improve the quality of plants. This procedure improves nutrient utilization and lower environmental pollution through reducing the amount of fertilizers added to soil. Foliar application of nutrients may actually promote root absorption of the same nutrient or other nutrients through improving root growth and increasing nutrients uptake (Romemheld and El-Fouly,1999).

Recently, among the fertilization strategies, the foliar spray with different molecules as humic acid has been introduced. These organic substances have no harmful threat to the quality of the environment (Senn, 
1991). Humic acid is a potential natural resource that can be utilized to increase growth, nutrient availability and yield (Sharif et al., 2002). Humic acid is a natural polymer containing carboxyl and phenolic positions to do exchange process. Humic acid (HA) is a relatively stable product of organic matter decomposition and thus accumulates in environmental systems. Humic acids make important contributions to improve soil stability, fertility, improves flower quality that lead to exceptional plant growth and micronutrient uptake. Humic acid is an effective agent to use as a compliment to fertilizer which is mostly used for soil reclamation which reduces the harmful effects of synthetic fertilizers and some other chemicals from the soil. It also has the potential for the economization of water and fertilizers (Dore and Peacock , 1997).

Few research works have been carried out on the use of humic substances in the production of ornamental plants. Arancon et al., (2003) demonstrated that humic acid increased growth of marigolds (Tagetes patula L. 'Antigua Gold'). Evans and Li (2003) studied the effect of humic acid on the growth of annual ornamental seedling i.e., Pansy, Marigold, Geranium, Vinca, and Impatiens. All vegetative and floral parameters significantly improved by increasing the HA concentration. Nikbakht et al., (2008) revealed that Humic acid produced visibly better and healthier plant growth and increased flower yield and quality of gerbera at $500 \mathrm{mg} \mathrm{L-1}$. Also, Pin et al .,(2011) mentioned stimulating effect of humic acid on growth and flowering of Salvia splendens. Moreover, Iftikhar et al., (2013) on gladiolus mentioned that applications of Humic acid (HA) and NPK, applied at planting and 3leaf stage, proved best for early and uniform sprouting, more foliage growth per plant, greater leaf area, and total leaf chlorophyll contents, earlier spike emergence, greater number of florets per spike, longer stems and spikes, and greater diameter of a spike, higher flower quality, longer vase life, higher number of cormels per clump, and greater cormel diameter and weight. In a pot experiment, Abdolrahman et al., (2014) study the effect of Humic acid application on qualitative characteristic and micronutrient status in Petunia hybrid L. The results revealed that the increase in humic acid concentration, increased all evaluated growth and flowering traits and an increase in micronutrient absorption was detected compared with the control.

The main objective of the present study was to investigate the effect of foliar spray of Humic acid with different doses and at different intervals on the growth, flower yield and quality of statice plants.

\section{MATERIALS AND METHODS}

An outdoor experimental study was conducted at Zuhria Botanical Garden, Horticultural Research Institute, Giza, Egypt. Statice plants cv. "Sunday Lavander" were grown throughout the two successive growth seasons (2013/2014) and (2014/2015).

\section{The Growing Medium and planting seeds:}

PVC pots (20 cm in diameter) were packed with medium consists of clay, peatmoss, and sand (2:1:1 $\mathrm{v} / \mathrm{v} / \mathrm{v})$, (Steven, 2008) . Each pot contained $2.0 \mathrm{~kg}$ medium.

Analyses of some chemical and physical properties of the used medium were carried out according to Page et al., (1982) and are presented in Tables (1) and (2).

Table 1. Some physical Properties of the growing medium

\begin{tabular}{lc}
\hline Property & Results of Analysis \\
\hline Coarse Sand, \% & 5.3 \\
Fine sand, \% & 30.6 \\
Silt, \% & 38.7 \\
Clay, \% & 25.4 \\
\hline
\end{tabular}

\section{Planting seeds and seedlings:}

One hundred statice seeds of cv "Sunday Lavander " were planted in each pot $(20 \mathrm{~cm}$ in diameter $)$ on $25^{\text {th }}$ September and $27^{\text {th }}$ September of the growth seasons 2013/2014 and 2014/2015, respectively. The seeds were covered with small layer of medium. Regular agricultural practices such as weeding and watering as basic dressing were carried out. Three weeks later, seedlings with $10 \mathrm{~cm}$ length, were primary transplanted in pots $(8-10 \mathrm{~cm}$ in diameter), each contained three seedlings. The seedlings were then kept for two weeks until good root formation obtained (Wilfret,1973). Then the seedlings were secondary transplanted in pots (20 $\mathrm{cm}$ in diameter), each contained one seedling on $1^{\text {st }}$ and $3^{\text {th }}$ November of the growth seasons 2013/2014 and 2014/2015, respectively.

Table 2. The main chemical properties of the growing medium

\begin{tabular}{|c|c|c|c|c|c|c|c|c|c|c|c|}
\hline \multirow[t]{2}{*}{ Growing medium } & \multirow{2}{*}{$\begin{array}{c}\text { EC } \\
\mathrm{ds} / \mathrm{cm}\end{array}$} & \multirow[t]{2}{*}{ pH } & \multicolumn{3}{|c|}{ Anions (meq/l) } & \multicolumn{3}{|c|}{ Cations (meq/l) } & \multicolumn{3}{|c|}{$\begin{array}{c}\text { Available } \\
\text { macro nutrients (ppm) }\end{array}$} \\
\hline & & & $\mathrm{HCO3}^{--}$ & $\mathrm{Cl}^{-}$ & $\mathrm{So4}^{-}$ & $\mathbf{C a}+$ & Mg+ & $\mathbf{N a}+$ & $\mathbf{N}$ & $\mathbf{P}$ & $\mathbf{K}$ \\
\hline $\begin{array}{l}\text { Clay, peatmoss, and sand } \\
(2: 1: 1 \mathrm{~V} / \mathrm{v} / \mathrm{v})\end{array}$ & 2.5 & 7.3 & 3.0 & 19.0 & 3.6 & 10 & 3.0 & 12 & 18.5 & 12 & 37 \\
\hline
\end{tabular}




\section{NPK Fertilizer:}

The recommended NPK water soluble fertilizer used was Kristalon $^{\mathrm{TM}}$ (19:19:19) Holland; $\mathrm{EC}=0.9 \mathrm{dS} / \mathrm{m}$, total $\mathrm{N} 19 \%\left(5.5 \% \mathrm{NO}_{3}-\mathrm{N}, 3.8 \% \mathrm{NH}_{4}-\mathrm{N}, 9.7 \%\right.$ urea $)$, $\mathrm{P}_{2} \mathrm{O}_{5}$ soluble in ammonium citrate $19 \%(8.3 \% \mathrm{P})$ and potassium oxide $\left(\mathrm{K}_{2} \mathrm{O}\right)$ soluble in water $19 \%(16.8 \%$ $\mathrm{K})$.

\section{The experimental Treatments:}

Statice plants were foliar sprayed on top of the leaves until run-off occurred with Humic acid solution $(25 \% \mathrm{w} / \mathrm{v})$ at three different doses of application (5 .0, 10.0, $15 \mathrm{~cm}^{3} /$ plant). The foliar spray was applied at either 15 day or 30 day intervals. All statice plants received the recommended NPK fertilization doses except for the unfertilized plants which did not receive any fertilizers. The NPK fertilization dose $3.0 \mathrm{~g} / \mathrm{plant}$ were applied monthly as dressing application throughout the growing seasons (Paparozzi and Hatterman, 1988). The first NPK fertilization dose was applied two weeks after final transplanting while the rest of doses were applied later at one month intervals.

The treatments were arranged in three replicates with eight plants in each experimental unit in a complete randomized block design. Data were statistically analyzed according to the methods described by Snedecor and Cochran, (1990). Differences among treatments were tested with Duncan Multiple Range test at 5\% level of significance. Regular agricultural practices such as weeding and watering as basic dressing were carried out for all treatments whenever necessary as recommended.

\section{Morphological Measurements:}

At the end of each growing season the following morphological measurements were carried out on the statice plants:

1- Vegetative growth characteristics: Plant height $(\mathrm{cm})$, number of leaves per plant, leaf area $\left(\mathrm{cm}^{2}\right)$, Number of branches/ plant, stem fresh and dry weight $(\mathrm{g})$ and fresh and dry weights of leaves $(\mathrm{g})$.

2- Flowering characteristics: Number of flowering stalk per plant, flowering stalk length $(\mathrm{cm})$, number of florets per flowering stalk and dry weight of florets per flowering stalk.

3- Root characteristics: dry weight of roots (g).

\section{Plant and Soil Analyses:}

To calculate the chlorophyll content in SPAD unites. At the flower bud initiation stage of each growing season, five leaves per plant were selected and chlorophyll content was measured by chlorophyll meter (SPAD 502) as described by Manetas et al.,
(1998). The SPAD-502 meter is a hand-held device that is widely used for the rapid, accurate and nondestructive measurement of leaf chlorophyll concentrations. In addition, chemical analyses of ovendry leaves (dried at $60{ }^{\circ} \mathrm{C}$ for $72 \mathrm{hr}$ ) were carried to determine their $\mathrm{N}, \mathrm{P}$ and $\mathrm{K}$ contents (\%) according to the methods outlined by Westerman (1990).

\section{RESULTS AND DISCUSSIONS}

\section{A- Vegetative growth characteristics:}

\section{1- Plant height (cm):}

Plant height was significantly affected by humic acid treatments as shown in Table (3). All treatments recorded higher significant values compared with the control (unfertilized plants) in both seasons. Applying 5 $\mathrm{cm}$ foliar humic acid at 30- day intervals gave the tallest plant height in both seasons. The increases in the recorded values were $19.40 \%$ and $13.56 \%$ relative to the recommended NPK applied alone, in the first and second season, respectively. Also, plants received 5 $\mathrm{cm}^{3}$ humic acid at 15 - day intervals gave superior significant records other than those received the recommended NPK alone.

Insignificant differences were recorded between plants received $5 \mathrm{~cm}$ foliar humic acid, either applied at 15- day or 30 day intervals. Also, it was noticed insignificant differences were recorded between plants received either 10 or $15 \mathrm{~cm}^{3}$ foliar humic acid applied at 30- day intervals. On the other hand, the plants received $10 \mathrm{~cm}$ foliar humic acid at 15 - day intervals, gave similar effects on plant height with those received the recommended NPK alone.

The finding is in line with those obtained by ElGhamry et al., (2009) reported that most of the morphological characteristics such as foliage height of faba bean plants significantly increased by foliar application of humic acid. Also, Behzad (2014) mentioned that foliar application of humic acid significantly affected plant height and highest values of this parameter was achieved under $2 \%$ foliar application.

\section{2- Leaf number / plant:}

Evidently data in Table (3) show that all humic acid treatments significantly increased this parameter compared with the control (unfertilized plants). The highest leaf number per plant was detected with plants received $15 \mathrm{~cm}^{3}$ humic acid at 30-day intervals with rates of increase of $5.01 \%$ and $6.28 \%$, relative the recommended NPK applied alone, in both seasons, respectively. Insignificant differences were detected between plants received either 5 or $10 \mathrm{~cm}^{3}$ humic acid, at 15- day intervals. 
Similar trend of results were observed by Yousef et al., (2011) who indicated that treated Chemlali olive seedlings with HA treatments gave the best results concerning leaf numbers. Iftikhar et al., (2013) reported that gladiolus plants receiving applications of HA and NPK produced the greatest number of leaves per plant.

\section{3- Leaf area $\left(\mathrm{cm}^{2}\right)$ :}

The results presented in Table (3) reveal that all humic acid treatments significantly affected leaf area and gave significant records other than the unfertilized plants. The plants received $15 \mathrm{~cm}^{3}$ humic acid at 30-day intervals gave the highest significant values. The increases in leaf area were $15.82 \%$ and $19.21 \%$ in the first and second season, respectively relative to the recommended NPK applied alone. No significant differences were detected due to applying either $5 \mathrm{~cm}$ or $10 \mathrm{~cm}$ humic acid at 30-day intervals.

Our findings is in accordance with those observed by Figliolia et al., (1994) they mentioned that foliar spray with humic acid increased leaf area index. Zaky et al., (2006) on bean plants found that the average leaf area of bean plants was increased by application of humic acid as a foliar fertilizer at a rate of $1 \mathrm{~g} / \mathrm{L}$. Also, Iftikhar et al., (2013) on gladiolus plants mentioned that applications of HA and NPK, applied at planting and 3leaf stage, proved best for more foliage growth per plant and greater leaf area.

Table 3. Effect of different Humic acid treatments on plant height $(\mathrm{cm})$, leaf number per plant, leaf area $\left(\mathrm{cm}^{2}\right)$ and number of branches per plant of Statice (Limonium sinuatum, L.) plants during the 2014 and 2015 seasons

\begin{tabular}{|c|c|c|c|c|}
\hline \multirow[t]{2}{*}{ Treatments } & $\begin{array}{l}\text { Plant height } \\
\text { (cm) }\end{array}$ & $\begin{array}{c}\text { Number of } \\
\text { Leaves/plant }\end{array}$ & $\begin{array}{l}\text { Leaf area } \\
\quad\left(\mathrm{cm}^{2}\right)\end{array}$ & $\begin{array}{c}\text { Number of } \\
\text { branches/ plant }\end{array}$ \\
\hline & \multicolumn{4}{|c|}{ First season (2013/2014) } \\
\hline Unfertilized plants & 41.26 & 18.03 & 51.64 & 1.66 \\
\hline $\begin{array}{l}\text { Foliar } 5 \mathrm{~cm}^{3} \text { at } 15 \text { day } \\
\text { intervals }\end{array}$ & 62.76 & 29.03 & 87.69 & 2.50 \\
\hline $\begin{array}{l}\text { Foliar } 10 \mathrm{~cm}^{3} \text { at } 15 \text { day } \\
\text { intervals }\end{array}$ & 55.36 & 30.00 & 105.51 & 3.16 \\
\hline $\begin{array}{l}\text { Foliar } 15 \mathrm{~cm}^{3} \text { at } 15 \text { day } \\
\text { intervals }\end{array}$ & 55.00 & 34.13 & 98.79 & 3.33 \\
\hline $\begin{array}{l}\text { Foliar } 5 \mathrm{~cm}^{3} \text { at } 30 \text { day } \\
\text { intervals }\end{array}$ & 63.20 & 30.36 & 106.55 & 3.30 \\
\hline $\begin{array}{l}\text { Foliar } 10 \mathrm{~cm}^{3} \text { at } 30 \text { day } \\
\text { intervals }\end{array}$ & 56.90 & 32.50 & 103.82 & 4.16 \\
\hline $\begin{array}{l}\text { Foliar } 15 \mathrm{~cm}^{3} \text { at } 30 \text { day } \\
\text { intervals }\end{array}$ & 58.76 & 34.40 & 113.97 & 4.33 \\
\hline NPK (Recommended) & 52.93 & 32.76 & 98.4 & 3.10 \\
\hline L.S.D $(0.05)$ & 5.21 & 5.42 & 9.43 & 1.05 \\
\hline Treatments & \multicolumn{4}{|c|}{ Second season $(2014 / 2015)$} \\
\hline Unfertilized plants & 44.46 & 19.63 & 49.96 & 1.05 \\
\hline $\begin{array}{l}\text { Foliar } 5 \mathrm{~cm}^{3} \text { at } 15 \text { day } \\
\text { intervals }\end{array}$ & 59.96 & 25.26 & 82.78 & 3.08 \\
\hline $\begin{array}{l}\text { Foliar } 10 \mathrm{~cm}^{3} \text { at } 15 \text { day } \\
\text { intervals }\end{array}$ & 58.06 & 28.66 & 96.63 & 3.50 \\
\hline $\begin{array}{l}\text { Foliar } 15 \mathrm{~cm}^{3} \text { at } 15 \text { day } \\
\text { intervals }\end{array}$ & 54.23 & 32.76 & 112.29 & 4.25 \\
\hline $\begin{array}{l}\text { Foliar } 5 \mathrm{~cm}^{3} \text { at } 30 \text { day } \\
\text { intervals }\end{array}$ & 59.96 & 28.96 & 106.28 & 3.25 \\
\hline $\begin{array}{l}\text { Foliar } 10 \mathrm{~cm}^{3} \text { at } 30 \text { day } \\
\text { intervals }\end{array}$ & 54.86 & 31.26 & 101.89 & 3.58 \\
\hline $\begin{array}{l}\text { Foliar } 15 \mathrm{~cm}^{3} \text { at } 30 \text { day } \\
\text { intervals }\end{array}$ & 55.66 & 34.33 & 113.41 & 4.25 \\
\hline NPK (Recommended) & 52.80 & 32.30 & 95.13 & 3.03 \\
\hline L.S.D $(0.05)$ & 4.86 & 4.43 & 7.48 & 0.93 \\
\hline
\end{tabular}

L.S.D $_{(0.05)}=$ Least significant difference at 0.05 level of probability. 


\section{4- Number of branches / plant:}

Applying all humic acid treatments resulted in significant increases in number of branches per plant compared with the control in both seasons, except for applying $5 \mathrm{~cm}^{3}$ humic acid at 15 - day intervals in the first season as shown in Table (3). The plants received $15 \mathrm{~cm}$ humic acid at 30-day intervals, gave the highest significant values with rates of increase of $39.67 \%$ and $42.26 \%$ relative to the recommended NPK applied alone, in both seasons, respectively. Also, it can be noticed that applying $10 \mathrm{~cm}^{3}$ humic acid at 30- day intervals gave similar results with the above mentioned treatment, in both seasons.

The obtained results are in harmony with those detected by Zaky et al., (2006) who found that the number of shoots/plant of bean plants was increased by application of humic acid as a foliar fertilizer at a rate of $1 \mathrm{~g} / \mathrm{L}$. Also, Yousef et al.,(2011) indicated that treated Chemlali olive seedlings with HA treatments gave the best results concerning brunch numbers per plant.

\section{5- Stem diameter (cm):}

The data presented in Table (4) revealed that applying all humic acid treatments resulted in significant increases in stem diameter compared with the control in both seasons. The highest significant values of stem diameter were observed after treatment with $10 \mathrm{~cm}^{3}$ humic at 30-day intervals in both seasons. The rates of increase were $16.32 \%$ and $7.84 \%$ relative to the recommended NPK applied alone, in both seasons, respectively. There were no significant differences detected among the previously mentioned treatment and the treatment with $5 \mathrm{~cm}^{3}$ humic acid at 30-day intervals.

The results are in harmony with those obtained by El-Nemr et al., (2012) reported that Cucumber plants were sprayed three times at 15 day intervals with different concentrations of humic acid weeks after planting. Recorded data showed that all morphological characters parameters including plant height, number of leaves and stems diameter as well as fresh weight of leaves/plant showed positive and significant responses with the high concentration of humic acid foliar applied.

\section{6- Stem fresh weight (g):}

Applying all humic acid treatments resulted in significant increases in stem fresh weight compared with the control in both seasons as shown in Table (4). The highest significant values of stem fresh weight were observed after treatment with $15 \mathrm{~cm}^{3}$ humic at 15-day intervals in both seasons. The rates of increase were $15.48 \%$ and $19.39 \%$ relative to the recommended NPK applied alone, in both seasons, respectively.
Furthermore, no significant differences were detected due to applying either 5 or $10 \mathrm{~cm}^{3}$ humic acid at 15 -day intervals.

The findings are in line with those obtained by Farahat et al., (2012) on Khaya senegalenssis seedlings reported that foliar application of humic acid at $4 \%$ gave the highest values of plant height, stem diameter as well as fresh and dry weights of stems.

\section{7- Stem dry weight (g):}

The results revealed that all foliar humic acid application treatments resulted in significant increases in stem dry weight compared with the control in both seasons as shown in Table (4). The highest significant values of stem dry weight were observed due to applying $15 \mathrm{~cm}$ humic at 15-day intervals in both seasons. The rates of increase were $20.53 \%$ and $47.51 \%$ relative to the recommended NPK applied alone, in both seasons, respectively. It can be also noticed that, there were no significant differences due to applying either 5 or $10 \mathrm{~cm}^{3}$ humic acid at 15 -day intervals, in both seasons. Moreover, theses treatments gave similar results with those obtained after treatment with the recommended NPK. Furthermore, no significant differences were detected due to applying either 10 or $15 \mathrm{~cm}^{3}$ humic acid at 30-day intervals.

The stimulating positive effect of humic acid application on stem fresh dry weights was also detected by Celik et al., (2008) on corn and oat seedling. Also, The El-Nemr et al ., (2012) reported that stem fresh and dry weights showed positive and significant responses with the high concentration of foliar applied humic acid.

\section{8- Fresh weight of leaves / plant (g):}

Appling all humic acid treatments resulted in significant increases in fresh weight of leaves compared with the control (Table 4). The treatment with $15 \mathrm{~cm}^{3}$ humic acid at 30-day intervals gave the highest significant values with rates of increase of $68.89 \%$ and $70.38 \%$ relative to the recommended NPK applied alone, in both seasons, respectively. Also, the data demonstrated that treatment with $10 \mathrm{~cm}^{3}$ humic acid at 30-day intervals had significant similar effects on fresh weight of leaves with the previously mentioned treatment. Also, applying $5 \mathrm{~cm}^{3}$ humic acid either at $15-$ day intervals or at 30-day intervals gave similar results with that obtained after treatment with the recommended NPK.

Similar results were observed by Farahat et al ., (2012) on Khaya senegalenssis seedlings reported that foliar application of humic acid at $4 \%$ gave the highest values of fresh and dry weights of leaves. 
Table 4. Effect of different Humic acid treatments on stem diameter $(\mathrm{cm})$, stem fresh and dry weights (g) and leaf fresh and dry weights (g) of Statice (Limonium sinuatum, L.) plants during the 2014 and 2015 seasons

\begin{tabular}{|c|c|c|c|c|c|}
\hline Treatments & $\begin{array}{c}\text { Stem } \\
\text { diameter } \\
\text { (cm) }\end{array}$ & $\begin{array}{l}\text { Stem fresh } \\
\text { weight } \\
\text { (g) }\end{array}$ & $\begin{array}{c}\text { Stem } \\
\text { dry weight } \\
\text { (g) }\end{array}$ & $\begin{array}{l}\text { Leaf fresh } \\
\text { weight } \\
\text { (g) }\end{array}$ & $\begin{array}{c}\text { Leaf } \\
\text { dry weight } \\
\text { (g) }\end{array}$ \\
\hline & \multicolumn{5}{|c|}{ First season $(2013 / 2014)$} \\
\hline Unfertilized plants & 0.40 & 8.20 & 1.51 & 7.91 & 1.56 \\
\hline $\begin{array}{l}\text { Foliar } 5 \mathrm{~cm}^{3} \text { at } 15 \text { day } \\
\text { intervals }\end{array}$ & 0.50 & 14.33 & 3.07 & 13.18 & 3.11 \\
\hline $\begin{array}{l}\text { Foliar } 10 \mathrm{~cm}^{3} \text { at } 15 \text { day } \\
\text { intervals }\end{array}$ & 0.55 & 15.46 & 3.40 & 18.39 & 5.94 \\
\hline $\begin{array}{l}\text { Foliar } 15 \mathrm{~cm}^{3} \text { at } 15 \text { day } \\
\text { intervals }\end{array}$ & 0.56 & 15.96 & 3.58 & 19.81 & 5.21 \\
\hline $\begin{array}{l}\text { Foliar } 5 \mathrm{~cm}^{3} \text { at } 30 \text { day } \\
\text { intervals }\end{array}$ & 0.55 & 13.47 & 2.14 & 16.15 & 7.44 \\
\hline $\begin{array}{l}\text { Foliar } 10 \mathrm{~cm}^{3} \text { at } 30 \text { day } \\
\text { intervals }\end{array}$ & 0.57 & 14.48 & 2.44 & 21.03 & 8.11 \\
\hline $\begin{array}{l}\text { Foliar } 15 \mathrm{~cm}^{3} \text { at } 30 \text { day } \\
\text { intervals }\end{array}$ & 0.54 & 14.54 & 3.38 & 22.21 & 8.41 \\
\hline NPK (Recommended) & 0.49 & 13.82 & 2.97 & 13.15 & 4.56 \\
\hline L.S.D $(0.05)$ & 0.017 & 1.23 & 0.65 & 3.25 & 1.52 \\
\hline Treatments & \multicolumn{5}{|c|}{ Second season $(2014 / 2015)$} \\
\hline Unfertilized plants & 0.410 & 8.26 & 1.84 & 7.39 & 1.72 \\
\hline $\begin{array}{l}\text { Foliar } 5 \mathrm{~cm}^{3} \text { at } 15 \text { day } \\
\text { intervals }\end{array}$ & 0.520 & 13.64 & 2.81 & 14.00 & 3.96 \\
\hline $\begin{array}{l}\text { Foliar } 10 \mathrm{~cm}^{3} \text { at } 15 \text { day } \\
\text { intervals }\end{array}$ & 0.520 & 14.13 & 2.84 & 16.14 & 6.13 \\
\hline $\begin{array}{l}\text { Foliar } 15 \mathrm{~cm}^{3} \text { at } 15 \text { day } \\
\text { intervals }\end{array}$ & 0.546 & 16.13 & 4.16 & 18.40 & 5.45 \\
\hline $\begin{array}{l}\text { Foliar } 5 \mathrm{~cm}^{3} \text { at } 30 \text { day } \\
\text { intervals }\end{array}$ & 0.546 & 13.31 & 2.49 & 18.37 & 7.51 \\
\hline $\begin{array}{l}\text { Foliar } 10 \mathrm{~cm}^{3} \text { at } 30 \text { day } \\
\text { intervals }\end{array}$ & 0.550 & 14.40 & 3.17 & 23.67 & 7.88 \\
\hline $\begin{array}{l}\text { Foliar } 15 \mathrm{~cm}^{3} \text { at } 30 \text { day } \\
\text { intervals }\end{array}$ & 0.540 & 15.48 & 3.50 & 23.70 & 9.24 \\
\hline NPK (Recommended) & 0.510 & 13.51 & 2.82 & 13.91 & 5.00 \\
\hline L.S.D $(0.05)$ & 0.018 & 1.46 & 0.61 & 4.72 & 1.50 \\
\hline
\end{tabular}

L.S.D $_{(0.05)}=$ Least significant difference at 0.05 level of probability.

Means with the same letter within the same column are not significantly differed.

\section{9- Dry weight of leaves / plant (g):}

Appling all humic acid treatments resulted in significant increases in dry weight of leaves compared with the control (Table 4). The treatment with $15 \mathrm{~cm}^{3}$ humic acid at 30-day intervals gave the highest significant values with rates of increase of $84.43 \%$ and $84.80 \%$ relative to the recommended NPK applied alone, in both seasons, respectively. Also, the data revealed that treatment with $10 \mathrm{~cm}^{3}$ humic acid at 30 day intervals had significant similar effects on dry weight of leaves with the previously mentioned treatment. Moreover, the data demonstrated that treatment with 10 or $15 \mathrm{~cm}^{3}$ humic acid at 15-day intervals had significant similar effects on dry weight of leave, in both seasons.

Similar trend of results was observed by Katkat et al., (2009) who reported that Humic acid applied to wheat as foliar spray $(0.1$ and $0.2 \%)$ had a significant positive effect on dry weight of leaves. Also, Yousef et al., (2011) indicated that treated Chemlali olive seedlings with HA treatments gave the best results concerning dry weight of leaves. Our findings confirm the work of Baldotto and Baldotto (2013) on gladiolus plants cv. 'White Friendship'. They mentioned that the 
stimulating effect on vegetative growth might be due to improvement of micro and macro nutrient uptake and reduction in water evaporation from soils.

The observed significant increase in the studied vegetative growth parameters as affected by applying humic acid could be explained by the fact that Humic acid is absorbed through plant roots, and translocated to shoots and other plant parts, and enhances plant growth responses (Lulakis and Petsas,1995). Research studies showed that humic acid can be used as a growth regulator to regulate hormone level and improve plant growth (Piccolo et al., 1992). Moreover, Humic acid can stimulate the plant growth by improving nutrient uptake and effects on hormones. Humic acid also has direct cytokinin (Zhang and Ervin, 2004) and auxin or gibberellin-like stimulatory effects (Pizzeghello et al., 2001). The hormone- like activities of HAs, in particular auxin-, cytokinin- and gibberellins-like effects (Piccolo et al., 1992 and Pizzeghello et al., 2002). The enhancing in growth parameters could be due to that plant growth hormones adsorbed onto the humates (Atiyeh et al., 2002). Also, the beneficial effect of humic acid on increasing: cell membrane, oxygen uptake, respiration and photosynthesis, nutrients uptake, root and cell elongation and ion transport, (Nardi et al. (2002).

Furthermore, Humic acid contains elements that improve soil fertility, reduces soil nutrient deficiency and increases water and nutrient availability by forming chelates of various nutrients (Sanchez-Sanchez et al., 2002). Humic acid can greatly benefit plant growth (Friedel and Scheller, 2002; Pin et al., 2011). Application of HA improves soil aggregation, structure, fertility, and moisture holding capacity, increases microbial activity, increase cell membrane permeability, increase oxygen uptake, respiration and photosynthesis, therefore enhance plant growth, (Sharif et al., 2002).

\section{B - Flowering Characteristics:}

\section{1- Number of flowering stalks / plant:}

Data in Table (5) demonstrate significant effect on number of flowering stalks per plant due to applying all humic acid treatments compared with the control. The highest number of stalks per plant was detected after treatment with $15 \mathrm{~cm}^{3}$ humic acid at 15-day intervals with the rates of increases of $43.75 \%$ and $31.17 \%$ relative to the recommended NPK applied alone in both seasons, respectively. The results indicated that, applying either 5 or $10 \mathrm{~cm}^{3}$ humic acid at 30-day intervals gave similar results with that obtained after treatment with the recommended NPK alone in both seasons.

The findings is in line with those obtained by Iftikhar et al., (2013) on gladiolus plants. They reported that the highest flower quality stems, greater number of florets per spike, longer stems and spikes, greater diameter of a spike, higher flower quality, were recorded in plants supplied with application of HA combined with NPK.

\section{2- Flowering stalk length (cm):}

It can be observed from the data in Table (5) the effectiveness of all humic acid treatments on flowering stalk length compared with the control. The highest recorded stalk length values were recorded after treatment with $15 \mathrm{~cm}^{3}$ humic acid at 30-day intervals with rates of increase of $28.75 \%$ and $29.81 \%$ relative to the recommended NPK applied alone in both seasons, respectively. Also, it was found that foliar application of the plants with $10 \mathrm{~cm}^{3}$ humic acid at 15-day intervals gave higher significant effect on stalk length with that obtained after applying the recommended NPK alone.

The results confirm the work of Iftikhar et al., (2013) who mentioned that application of HA and NPK, applied at 3-leaf stages of gladiolus plant development, proved best for longer stems and spikes. Ahmed et al., (2015) mentioned that application of humic acid combined with NPK resulted in significant increases in stalk length of Tulipa gesneriana. This may be due to improvement of plant growth in terms of stem elongation by hormone like activity of HA. Also, Behnam et al., (2015) reported that application of humic acid resulted in the highest flowering stalk height and spike height of tuberose plants.

\section{3- Number of florets /flowering stalk:}

Data in Table (5) demonstrate significant effect on number of florets per flowering stalk due to applying all humic acid treatments compared with the control .The highest number of florets per flowering stalk was detected after treatment with $10 \mathrm{~cm}^{3}$ humic acid at 30 day intervals with the rates of increases of $57.76 \%$ and $77.37 \%$ relative to the recommended NPK applied alone in both seasons, respectively. Moreover, it can be noticed that applying $15 \mathrm{~cm}^{3}$ humic acid at 15-day intervals gave higher significant effects over the recommended NPK applied alone. Also, the results revealed that, applying $5 \mathrm{~cm}^{3}$ humic acid at 15-day intervals gave similar results with that obtained after treatment with the recommended NPK alone in both seasons.

The findings are in harmony with those obtained by Iftikhar et al., (2013) who reported that application of HA and NPK, applied at 3-leaf stages of gladiolus plant development, proved best for greater number of florets per spike. Also, Behnam et al., (2015) mentioned that application of humic acid increased the number of florets per spike of tuberose plants. 


\section{3- Dry weight of florets / flowering stalk (g):}

It is obvious from data in Table (5) that humic acid treatments were significantly affected dry weight of florets per flowering stalk. The superiority of dry weight of florets per flowering stalk was recorded with plants received $10 \mathrm{~cm}^{3}$ humic acid at 30-day intervals with rates of increases of $38.47 \%$ and $44.26 \%$ relative to the recommended NPK applied alone in both seasons, respectively. Moreover, the resulted proved that applying $15 \mathrm{~cm}^{3}$ humic acid at 15-day intervals gave significantly higher values than that obtained after treatment with the recommended NPK alone in both seasons.

Table 5. Effect of different Humic acid treatments on number of flowering stalk / plant, flowering stalk length (cm), number of florets / flowering stalk, dry weight of florets/ flowering stalk and dry weight of roots (g) of Statice (Limonium sinuatum, L.) plants during the 2014 and 2015 seasons

\begin{tabular}{|c|c|c|c|c|c|}
\hline Treatments & $\begin{array}{c}\text { Number of } \\
\text { flowering } \\
\text { stalk / plant }\end{array}$ & $\begin{array}{c}\text { Flowering } \\
\text { Stalk length } \\
\text { (cm) }\end{array}$ & $\begin{array}{c}\text { Number of } \\
\text { florets / } \\
\text { flowering stalk }\end{array}$ & $\begin{array}{c}\text { Dry weight of } \\
\text { florets / flowering } \\
\text { stalk (g) }\end{array}$ & $\begin{array}{l}\text { Dry weight of } \\
\text { roots } \\
\text { (g) }\end{array}$ \\
\hline & \multicolumn{5}{|c|}{ First season $(2013 / 2014)$} \\
\hline Unfertilized plants & 2.10 & 8.60 & 7.50 & 0.193 & 0.73 \\
\hline $\begin{array}{l}\text { Foliar } 5 \mathrm{~cm}^{3} \text { at } 15 \\
\text { day intervals }\end{array}$ & 2.76 & 10.46 & 10.90 & 0.636 & 1.17 \\
\hline $\begin{array}{l}\text { Foliar } 10 \mathrm{~cm}^{3} \text { at } 15 \\
\text { day intervals }\end{array}$ & 4.20 & 11.56 & 10.90 & 0.703 & 1.48 \\
\hline $\begin{array}{l}\text { Foliar } 15 \mathrm{~cm}^{3} \text { at } 15 \\
\text { day intervals }\end{array}$ & 4.60 & 11.36 & 16.43 & 0.830 & 1.53 \\
\hline $\begin{array}{l}\text { Foliar } 5 \mathrm{~cm}^{3} \text { at } 30 \\
\text { day intervals }\end{array}$ & 3.43 & 12.56 & 13.53 & 0.716 & 0.93 \\
\hline $\begin{array}{l}\text { Foliar } 10 \mathrm{~cm}^{3} \text { at } 30 \\
\text { day intervals }\end{array}$ & 3.80 & 13.03 & 16.66 & 0.853 & 1.28 \\
\hline $\begin{array}{l}\text { Foliar } 15 \mathrm{~cm}^{3} \text { at } 30 \\
\text { day intervals }\end{array}$ & 4.33 & 10.86 & 16.60 & 0.810 & 1.03 \\
\hline NPK (Recommended) & 3.2 & 10.33 & 10.56 & 0.616 & 1.11 \\
\hline L.S.D $(0.05)$ & 0.62 & 0.56 & 2.44 & 0.105 & 0.198 \\
\hline Treatments & \multicolumn{5}{|c|}{ Second season $(2014 / 2015)$} \\
\hline Unfertilized plants & 2.10 & 8.40 & 6.86 & 0.263 & 0.68 \\
\hline $\begin{array}{l}\text { Foliar } 5 \mathrm{~cm}^{3} \text { at } 15 \\
\text { day intervals }\end{array}$ & 3.33 & 10.70 & 9.20 & 0.623 & 1.30 \\
\hline $\begin{array}{l}\text { Foliar } 10 \mathrm{~cm}^{3} \text { at } 15 \\
\text { day intervals }\end{array}$ & 3.76 & 11.96 & 12.06 & 0.810 & 1.54 \\
\hline $\begin{array}{l}\text { Foliar } 15 \mathrm{~cm}^{3} \text { at } 15 \\
\text { day intervals }\end{array}$ & 4.46 & 10.80 & 16.90 & 0.763 & 1.66 \\
\hline $\begin{array}{l}\text { Foliar } 5 \mathrm{~cm}^{3} \text { at } 30 \\
\text { day intervals }\end{array}$ & 3.10 & 12.20 & 13.16 & 0.603 & 1.21 \\
\hline $\begin{array}{l}\text { Foliar } 10 \mathrm{~cm}^{3} \text { at } 30 \\
\text { day intervals }\end{array}$ & 3.40 & 13.63 & 17.56 & 0.880 & 1.20 \\
\hline $\begin{array}{l}\text { Foliar } 15 \mathrm{~cm}^{3} \text { at } 30 \\
\text { day intervals }\end{array}$ & 3.73 & 11.60 & 17.00 & 0.746 & 0.98 \\
\hline NPK (Recommended) & 3.40 & 10.50 & 9.90 & 0.610 & 1.15 \\
\hline L.S.D $(0.05)$ & 0.69 & 0.67 & 1.35 & 0.099 & 0.26 \\
\hline
\end{tabular}

L.S.D $_{(0.05)}=$ Least significant difference at 0.05 level of probability.

Means with the same letter within the same column are not significantly differed. 
Similar trend of results was observed on flowering characteristics as a result of HA application with several studies i,e. Evans and Li (2003) studied the effect of humic acid on the growth of annual ornamental seedling: Pansy, Marigold, Geranium, Vinca, and Impatiens. They observed that all floral parameters significantly improved by increasing the HA concentration. Iftikhar et al. (2013) on gladiolus who found that applications of HA and NPK, applied at planting and 3-leaf stage, proved best for greater number of florets per spike, longer stems and spikes, and greater diameter of a spike, higher flower quality and longer vase life. When plants were supplied with three applications of HA and NPK, thicker spikes than with other treatments were recorded. Gladiolus cv. 'Corveira' stems had thicker spikes than 'Eminence' or 'Essential'. Regarding flower quality, among HA treatments, highest flower quality stems were recorded in plants supplied with three applications of HA and NPK, while those without HA or NPK application had the lowest quality stems. Gladiolus cv. 'Fado' stems had higher quality spikes than all other cultivars. Also, Ahmed et al., (2015) mentioned that application of humic acid combined with NPK resulted in significant increases in fresh and dry flower biomass of Tulipa gesneriana.

The stimulating effects of humic acid application on flowering characteristics could be due to that HAs have auxin-like activity that enhanced the nutrient uptake which may be responsible for the good floral growth (Kulikova et al., 2005). Moreover, the presence of humic molecules raised the effect on plants of the fertilization based on nitrogen, phosphorus and potassium(Pollhamer, 1993). In addition the enhancement in flower yield and quality could be attributed to the greatly improved biometric characteristics such as photosynthetic activity, N metabolism and protein synthesis besides, the increase in leaves number per plant, which in turn supplied more photosynthates leading to produce more flowers with high quality (Baldotto and Baldotto, 2013).

\section{C- Root characteristics: \\ Dry weight of roots:}

Data illustrated in Table (5) reveal significant effect on dry weight of roots as a result of applying humic acid treatments. The treatment with $15 \mathrm{~cm}^{3}$ humic acid at 15-day intervals gave the highest significant values of root dry with rates of increase of $37.83 \%$ and $44.34 \%$ relative to the recommended NPK applied alone, in both seasons, respectively. Also, it was found that foliar application with either $10 \mathrm{~cm}$ or $15 \mathrm{~cm}^{3}$ humic at 15-day intervals gave similar effects on root dry weight, in both seasons and both treatments were superior over applying the recommended NPK alone.

The significant increase detected in root dry weight with humic acid application confirm the work of Dore and Peacock (1997)who reported that humic substances act as a soil conditioner for turf grass growth and improved root growth. Liu et al., 1998 on creeping bentgrass. Also, Autio (2000) on gerbera who stated that Humic acid application increased nutrient uptake and hormone-like properties led to the increase of lateral roots of gerbera flowers. Humic acid foliar application were effective in maintaining higher root fresh and dry weights in marigold, pansy (Viola tricolor L.), geranium (Pelargonium $\times$ hortorum L. H. Bailey), and impatiens (Impatiens walleriana Hook. f.) seedlings (Li and Evens, 2000). Also, Arancon et al., (2003) demonstrated that humic acid increased root growth of marigolds (Tagetes patula L.'Antigua Gold') and peppers (Capsicum annuum L. 'King Arthur'.Also, better root growth was observed in gerbera (Gerbera jamesonii) as a result of applying HA (Nikbakht et al., 2008). Chang et al.,(2012) in a study on lilium found that humic acid improved root development.

Such results could be due to that humic acid has active role in improving roots dimension by increasing division and elongation of cell, and in tern enhanced nutrients absorption. The physiological mechanism has not been well established. Root development is due to not only the hormone-like effects of humic acid, but also is due to increased absorption of nutrients in the root (Liu et al., 1998).

\section{D- Chlorophylls and Nutrients Contents of Statice leaves: \\ 1- Total chlorophylls content of Leaves:}

As shown in Table (6) total chlorophylls content seemed to be increased with all humic acid treatments compared with the control (unfertilized plants). The highest values of chlorophylls were observed after treatment with $15 \mathrm{~cm}^{3}$ humic acid at 15-day intervals with rates of increase of 12.43 and $16.21 \%$ relative to the recommended NPK applied alone, in both seasons, respectively. Also, the results indicated that foliar application with $10 \mathrm{~cm}^{3}$ humic acid at 15-day intervals gave higher significant values than those obtained after treatment with the recommended NPK applied alone.

The results are in accordance with those obtained by Russo and Berlyn, (1990) who revealed that chlorophyll contents of Lolium perenne were significantly increased by HA application. El-Ghamry et al., (2009) reported that chlorophyll content of faba bean plants significantly increased by foliar application of humic acid. Farahat et al., (2012) reported that foliar 
application of humic acid at $4 \%$ gave the highest values of leaf chlorophyll content of khaya senegalensis seedlings. Moreover, Iftikhar et al.,(2013) on gladiolus plants mentioned that applications of HA and NPK, applied at planting and 3-leaf stage, proved best for total leaf chlorophyll contents. Also, Mohsen (2014) mentioned that humic acid foliar spray affected tomato leaf chlorophyll content significantly.

The significant increase in leaf chlorophylls content as a result of applying humic acid foliar application could be due to increasing the availability of nitrogen, consequently increasing its absorption by the plant the acceleration of $\mathrm{N}$ uptake, enhancing $\mathrm{N}$ metabolism and production of protein that ultimately increase chlorophyll contents (Haghighi et al., 2012). Another explain could be due the function of Humic acid which play an important role in increasing cell membrane permeability, oxygen uptake, respiration and photosynthesis, phosphate uptake, and root elongation (Russo and Berlyn, 1990).

\section{2- Nutrients Contents of Leaves:}

Results of the plant leaves analyses for their N, P and $\mathrm{K}$ contents (\%) are listed in Table (6). The data demonstrate that all humic acid treatments significantly affected NPK contents of statice leaves.

Statistical analysis of these results revealed that the highest significant values of leaf nitrogen content were detected after treatment with $15 \mathrm{~cm}$ humic acid at 15 day intervals in both seasons with rates of increase $10.56 \%$ and $13.07 \%$ relative to the recommended NPK applied alone, in both seasons, respectively. Meanwhile, the application with $10 \mathrm{~cm}^{3}$ humic acid applied at 15-day intervals resulted in significantly higher nitrogen content values than those obtained after treatment with the recommended NPK applied alone, in both seasons.

In case of phosphorus contents of statice leaves (Table 6), the foliar application with $15 \mathrm{~cm}^{3}$ humic acid at 15- day intervals gave the highest significant values with rates of increase $50 \%$ and $50 \%$ relative to the recommended NPK applied alone, in both seasons, respectively. The foliar application with either 5 or 10 $\mathrm{cm}^{3}$ humic acid at 15-day intervals had similar effects on leaf phosphorus effects and both of them had higher significant phosphorus values than those obtained after treatment with the recommended NPK applied alone. Moreover, it can be noticed, no significant differences were observed due to applying either 5 or $10 \mathrm{~cm}^{3}$ humic acid at 30-day intervals and both of them had similar effect.

The effects of the humic acid treatments on the potassium content of statice leaves were also significant as shown in Table (6). The foliar application with 15 $\mathrm{cm}^{3}$ humic acid at 15-day intervals resulted in the highest significant values of potassium leaf content with rates of increase of $12.92 \%$ and $15.02 \%$ relative to the recommended NPK applied alone, in both seasons, respectively. Moreover, the results indicated that the application with $10 \mathrm{~cm}^{3}$ humic acid applied at either 15day or 30-day intervals resulted in significantly higher potassium content values than those obtained after treatment with the recommended NPK applied alone, in both seasons.

Several studies agree with our findings and demonstrate the beneficial influence of humic acid on leaf NPK accumulation in different crops i.e., El-Desuki (2004) concluded that humic acid as foliar sprays enhanced growth nutrient uptake and yield and improved the quality of onion plants, this may be decrease the N,P,K applied as soil application which decrease pollution and costs. Ayas et al., (2005) on spinach plants reported that humic acid had significant effects regarding leaves NPK uptake. Ilias et al., (2007) on okra found that application of HA promoted the accumulation of $\mathrm{K}, \mathrm{B}, \mathrm{Mg}, \mathrm{Ca}$ and $\mathrm{Fe}$ in leaves. Also, Celik et al., (2008) reported that HA significantly increased mineral-nutrients uptake. Nikbakht et al., (2008) mentioned that Humic acid application has beneficial effect on nutrient uptake in gerbera (Gerbera jamesonii ), particularly uptake of $\mathrm{N}, \mathrm{P}, \mathrm{K}, \mathrm{Mg}, \mathrm{Ca}, \mathrm{Zn}$, $\mathrm{Fe}$, and $\mathrm{Cu}$ by plants. Also, Morad et al., (2011) on maize plant detected similar effect. Ayas and Gulser (2005) reported that HA application was the main reason of enhanced nitrogen uptake in spinach leaves. Katkat et al.,(2009) reported that humic acid applied to wheat as foliar spray $(0.1$ and $0.2 \%)$ had a significant positive effect on NPK uptake. Mahmoud et al., (2011) mentioned that N, P and K content of Soybean plants considerably increased as a result of soil or foliar application of HA. In addition, El-Nemr et al ., (2012) revealed that the total chemical contents percentage $(\mathrm{N}$, $\mathrm{P}$ and $\mathrm{K}$ ) in leaves of cucumber plants increased with increasing the amount of humic acid level $(3 \mathrm{~g} / \mathrm{L})$. Haghighi et al., (2012) on lettuce mentioned that humic acid enhanced nutrient absorption.

The obtained results of leaf NPK uptake can be explained by the better development root systems and increase in the permeability of plant membranes (David et al.1994). Furthermore, humic substances may interact with the phospholipids structures of cell membranes and react as carriers of nutrients through them (Ulukan, 2008). Humic substances affect the solubility of many nutrient elements by building complex forms or chelating agents of humic matter with metallic cations (Lobartini et al.,1997). 
Table 6. Effect of different Humic acid treatments on leaf chlorophyll content (SPAD unites), leaf Nitrogen, Phosphorus and Potassium contents(\%) of Statice (Limonium sinuatum, L.) plants during the 2014 and 2015 seasons

\begin{tabular}{|c|c|c|c|c|}
\hline \multirow[t]{2}{*}{ Treatments } & $\begin{array}{c}\text { Chlorophyll } \\
\text { content } \\
\text { (SPAD unites) }\end{array}$ & $\begin{array}{c}\text { Leaf Nitrogen } \\
\text { content } \\
(\%)\end{array}$ & $\begin{array}{l}\text { Leaf Phosphorus } \\
\text { content } \\
(\%)\end{array}$ & $\begin{array}{l}\text { Leaf Potassium } \\
\text { content } \\
(\%)\end{array}$ \\
\hline & \multicolumn{4}{|c|}{ First season $(2013 / 2014)$} \\
\hline Unfertilized plants & 10.03 & 1.21 & 0.10 & 1.08 \\
\hline $\begin{array}{l}\text { Foliar } 5 \mathrm{~cm}^{3} \text { at } 15 \text { day } \\
\text { intervals }\end{array}$ & 17.21 & 2.64 & 0.23 & 2.41 \\
\hline $\begin{array}{l}\text { Foliar } 10 \mathrm{~cm}^{3} \text { at } 15 \text { day } \\
\text { intervals }\end{array}$ & 19.53 & 2.83 & 0.24 & 2.61 \\
\hline $\begin{array}{l}\text { Foliar } 15 \mathrm{~cm}^{3} \text { at } 15 \text { day } \\
\text { intervals }\end{array}$ & 19.72 & 2.93 & 0.27 & 2.71 \\
\hline $\begin{array}{l}\text { Foliar } 5 \mathrm{~cm}^{3} \text { at } 30 \text { day } \\
\text { intervals }\end{array}$ & 12.26 & 2.17 & 0.16 & 2.38 \\
\hline $\begin{array}{l}\text { Foliar } 10 \mathrm{~cm}^{3} \text { at } 30 \text { day } \\
\text { intervals }\end{array}$ & 15.27 & 2.37 & 0.18 & 2.47 \\
\hline $\begin{array}{l}\text { Foliar } 15 \mathrm{~cm}^{3} \text { at } 30 \text { day } \\
\text { intervals }\end{array}$ & 17.84 & 2.57 & 0.14 & 2.60 \\
\hline NPK (Recommended) & 17.54 & 2.65 & 0.18 & 2.40 \\
\hline L.S.D $(0.05)$ & 0.470 & 0.060 & 0.020 & 0.049 \\
\hline Treatments & \multicolumn{4}{|c|}{ Second season $(2014 / 2015)$} \\
\hline Unfertilized plants & 10.45 & 1.24 & 0.09 & 1.07 \\
\hline $\begin{array}{l}\text { Foliar } 5 \mathrm{~cm}^{3} \text { at } 15 \text { day } \\
\text { intervals }\end{array}$ & 15.67 & 2.83 & 0.26 & 2.41 \\
\hline $\begin{array}{l}\text { Foliar } 10 \mathrm{~cm}^{3} \text { at } 15 \text { day } \\
\text { intervals }\end{array}$ & 18.57 & 2.78 & 0.30 & 2.54 \\
\hline $\begin{array}{l}\text { Foliar } 15 \mathrm{~cm}^{3} \text { at } 15 \text { day } \\
\text { intervals }\end{array}$ & 19.28 & 2.94 & 0.33 & 2.68 \\
\hline $\begin{array}{l}\text { Foliar } 5 \mathrm{~cm}^{3} \text { at } 30 \text { day } \\
\text { intervals }\end{array}$ & 15.21 & 2.81 & 0.18 & 2.36 \\
\hline $\begin{array}{l}\text { Foliar } 10 \mathrm{~cm}^{3} \text { at } 30 \text { day } \\
\text { intervals }\end{array}$ & 16.69 & 2.78 & 0.19 & 2.41 \\
\hline $\begin{array}{l}\text { Foliar } 15 \mathrm{~cm}^{3} \text { at } 30 \text { day } \\
\text { intervals }\end{array}$ & 18.18 & 2.84 & 0.20 & 2.52 \\
\hline NPK (Recommended) & 16.59 & 2.60 & 0.22 & 2.33 \\
\hline L.S.D $(0.05)$ & 0.292 & 0.092 & 0.021 & 0.062 \\
\hline
\end{tabular}

L.S.D $_{(0.05)}=$ Least significant difference at 0.05 level of probability.

Moreover, indirect effects of humic acid involve improvement of the soil properties such as aggregation, aeration, permeability, water holding capacity, nutrients transport and availability (Tan, 2003).

From the obtained data it can be concluded that Humic acid foliar application is a potential compound that can be used for increasing nutrient availability thus stimulating growth and flowering characteristics of statice plants (Limonium sinuatum, L.) cv. "Sunday Lavander".

\section{REFERENCES}

Abdolrahman, R. ; Ebrahim, Sh. and Abolfazl, G. 2014. Effect of Humic Acid Application on Qualitative Characteristic and Micronutrient Status in Petunia hybrid L. Bull. Env. Pharmacol. Life Sci., 3 (9): 15-19.

Ahmad, A., Shoaib. U., Sami, U., and Sajjad, R.2015. Combined effect of Humic Acid and NPK on growth and flower development of Tulipa gesneriana in Faislabad, Pakistan. IJAVMS, 9 (1): 18-28. 
Khan, 2014. Enhancing the vase life of tulipa (TulipaGesneriana L.) using various pulsing solutions of humicacide and NPK. International journal of plant, Animal and Environmental Sciences, 4(2): 193-200.

Arancon, N.Q., S. Lee, C.A. Edwards, and R. Atiyeh. 2003. Effect of humic acids derived from cattle, food and paperwaste vermicompost on growth of green house plants. Pedobiologia, 47:741-744.

Atiyeh, R.M., Lee, S., Edwards, C.A., Arancon, N.Q., and Metzger, J.D. 2002. The influence of humic acids derived from earthworm-processed organic wastes on plant growth. Bioresource Technology,84:7-14.

Autio, J. 2000. Supplementary lighting regimes strongly affect the quantity of gerbera flower yield. Acta Hort. 515:9198 .

Ayas, H., and Gulser, F. 2005. The effects of sulfur and humic acid on yield components and macronutrient contents of spinach. J. Biol. Sci., 5(6): 801-804.

Baldotto, M.A., and L.E.B. Baldotto. 2013. Gladiolus development in response to bulb treatment with different concentrations of humic acids. Revista Ceres 60:138-142.

Behzad, S. 2014. Foliar application of Humic Acid on plant height in Canola. APCBEE Procedia, 8: 82- 86.

Behnam, K., Amrollah, N. and Behrooz, S. 2015. The effect of different levels of Humic Acid and Salicylic acid on growth characteristics and qualities of Tuberose. Advances in Environmental Biology, 8(16):118-123.

Celik, H., Katkat, A.V., Ayk, B.B., and Turan, M.A. 2008. Effects of Soil Application of Humus on Dry Weight and Mineral Nutrients Uptake of Maize under Calcareous Soil Conditions. Archives of Agron. Soil Sci., 54(6): 605-614.

Chang, L., Y. Wu, W. Xu, A. Nikbakht and Y. Xia, 2012. Effects of calcium and humic acid treatment on the growth and nutrient uptake of Oriental lily. African Journal of Biotechnology , 11(9): 2218-2222.

Dore, S.P., and C.H. Peacock. 1997. The effect of humate and organic fertilizers on establishment and nutrition of creeping bent grasses. Int. Turfgrass. Soc. R. J. 8: 437444.

El-Desuki M. 2004. Response of onion plants to humic acid and mineral fertilizers application. Annals of Agric. Sci., Moshtohor, 42(4):1955-1964.

El-Ghamry, A.M.; K.M. Abd El-Hadi and K.M. Ghoneem. 2009. Amino and humic acids promote growth, yield and disease resistance of faba bean cultivated in clayey soil. Australian J. of Basic Applied Sciences,3(2): 731-739.

El-Nemr M.A. ; El-Desuki M. ; El-Bassiony A.M. and Fawzy, Z.F.2012. Response of growth and yield of cucumber plants (Cucumis sativus, L.) to different foliar applications of humic acid and bio-stimulators. Australian Journal of Basic and Applied Sciences, 3:630-637.

Fagbenro, J.A., and A.A. Agboola. 1993. Effect of different levels of humic acid on the growth and nutrient uptake of teak seedlings. Journal of Plant Nutrition 16:1465-1483.

Farahat, M.M. Farahat, Mazhar, A.A.M. and Mahgoub, M.H. 2012. Response of Khaya senegalensis seedlings to Iirigation intervals and foliar application of Humic acid. J. Hort. Sci. \& Ornamen. Plants, 4 (3): 292-298.
Figliolia A.; Benedetti A.; Izza C.; Indiati, R.; Rea, E.; Alianiello, F.; Canali, S.; Biondi, F.A.; Pierandrei, F.; and Moretti, R. 1994. Effects of fertilization with humic acid on soils and plant metabolism: A multidisciplinary approach. Note I: Crop production, in: Humic Substances in the Global Environment and Implications on Human Health Proceedings of the 6th International Meeting of the International Humic Substances Society, Elsevier Science Publishers, Amsterdam, The Netherlands, pp. 579-584.

Friedel, J.K., and E. Scheller. 2002. Composition of hydrolysable amino acids in soil organic matter and soil microbial biomass. Soil Biology and Biochemistry 34:315-325.

Haghighi, M., M. Kafi, and P. Fang. 2012. Photosynthetic activity and $\mathrm{N}$ metabolism of lettuce as affected by humic acid. International Journal of Vegetable Science 18:182189.

Iftikhar Ahmad, Rana Usman Saquib, Muhammad Qasim, Muhammad Saleem, Ahmad Sattar Khan, and Muhammad Yaseen .2013. Humic acid and cultivar effects on growth, yield, vase life, and corm characteristics of gladiolus. Chilean journal of agricultural research 73(4):339-344.

Ilias, I., Ouzounidou, G., Giannakoula, A., and Papadopoulou, P. 2007. Effects of gibberellic acid and prohexadionecalcium on growth, chlorophyll fluorescence and quality of Okra plant. Biol. Plantarum 51(3): 575-578.

Kulikova, N.A., E.V.,Stapanoava. and Koroleva, O.V. 2005. Mitigating activity of humic substances: Direct influence on Biota. In: Use of humic substances to remediate polluted environment: from theory to practices: Earth and environmental series, Permenova, IV. (eds). Kluwer Acedemic Publisher, USA. ISBN: p: 285-309.

Li, G., and M.R. Evens. 2000. Humic acid substrate treatments and foliar spray application effects on root growth and development of seedlings. HortScience 35:434.

Liu, C.H., Cooper, R.J., and D.C Bowman. 1998. Humic acid application affects photosynthesis, root development, and nutrient content of creeping bentgrass. HortScience 33: 1023-1025.

Lulakis, M.D., and S.I. Petsas. 1995. Effect of humic substances from vine-canes mature compost on tomato seedling growth. Bioresource Technology 54:179-182.

Mahmoud, M. M. ; A. H. A. Hassanein; S. F. Mansour and A. M. Khalefa.2011. Effect of soil and foliar application of humic acid on growth and productivity of soybean plants grown on a calcareous soil under different levels of mineral fertilizers. J. Soil Sci. and Agric. Eng., Mansoura Univ., 2 (8): $881-890$.

Malik, K.A. and F., Azam. 1985. Effect of humic acid on wheat (Triticum aestivum L.) seedling growth, Environ. Exp. Bot. 25, 245-252.

Manetas Y., G.,Grammatikopoulos. and Kyparissis, A.1998. The use of the portable, non-destructive, SPAD-502 (Minolta) chlorophyll meter with leaves of varying trichome density and anthocyanin content. J.Plant Physiol. 153: 513 -516. 
Morard, P., Eyheraguibel, B., Morard, M., and Silvestre, J. 2011. Direct effects of humic-like substance on growth, water, and mineral nutrition of various species. J. Plant Nutr. 34(1):46-59.

Mohsen, K. 2014. Effect of foliar application of Humic Acid and Calcium Chloride on tomato growth. Bull. Env. Pharmacol. Life Sci., 3 (3): 41- 46.

Nikbakht, A., M. Kafi, M. Babalar, Y.P. Xia, A. Luo, and N. Etemadi. 2008. Effect of humic acid on plant growth, nutrient uptake, and postharvest life of gerbera. Journal of Plant Nutrition 31:2155-2167.

Page, A.L. ; R.H. Miller and D.R. Keeney. 1982. Methods of Soil Analysis. Am. Soc. Agron. Madison, Wisconsin, USA.

Paparozzi, ET and Hatterman, H.M. 1988. Fertilizer applications on field grown Statice. Hortscience, 23:157160.

Piccolo, A., S. Nardi, and G. Concheri. 1991. Structural characteristics of humic Substances as related to nitrate uptake and growth regulation in plant systems. Soil Biology and Biochemistry 23:833-836.

Piccolo, A., Nardi, S. and Concheri, G. 1992. Structural characteristics of humic substances as regulated tonitrate uptake and growth regulation in plant systems, Soil Biol. Biochem. 24, 373-380.

Pizzeghello, D. , Nicolini, G. and Nardi, S. 2002. Hormonelike activities of humic substances in different forest ecosystems. New Phytol 155, 393- 402.

Pin, L., S. Guang, and Z. Lin. 2011. Effect of humic acid from straw on growth and pest resistance of Salvia splendens. en.cnki.com. cn. doi:cnki:sun:fzsa.

Romemheld, V., and El-Fouly, M.M. 1999. Foliar nutrient application, Challenge and limits in crop production, Proc. 2nd International Workshop on "Foliar Fertilization" April 4-10 Bangkok, Thailand. pp: 1-32.

Russo, R.O., and G.P. Berlyn. 1990. The use of organic biostimulants to help low input sustainable agriculture. Journal of Sustainable Agriculture 1:19-42.
Sanchez-Sanchez, A., J. Sanchez-Andreu, M. Juarez, J. Jorda, and D. Bermudez. 2002. Humic substances and amino acids improve effectiveness of chelate FeEDDHA in lemon trees. Journal of Plant Nutrition 25:2433-2442.

Senn, T.L. 1991. Humates in Agriculture, Acres USA, Jan.

Sharif, M., R.A. Khattak, and M.S. Sarir. 2002. Effect of different levels of lignitic coal derived humic acid on growth of maize plants. Communication in Soil Science and Plant Analysis 33:3567-3580.

Snedecor, C.W. and W.G. Cochran. 1990. Statistical Methods, $9^{\text {th }}$ Ed., Iowa State Univ. Press, Ames, Iowa, USA.

Steven W.B. 2008. Florist Review: Fresh Flower Limonium. http:/www.floristsreview.com/main/october2008/freshflo wer1008.html.

Tan, K.H. 2003. Humic matter in soil and environment. Principles and Controversies, Marcel Dekker, Inc. 270 Madison Avenue, New York.

Westerman, R.L. 1990. Soil Testing and Plant Analysis. (3 ${ }^{\text {rd }}$ ed) Soil Science Society of America, Inc. Madison Wisconsin, USA.

Wilfret, G.J, Raulston, J.C, Poe S.L, and Engelhard, A.W.1973. Cultural Techniques for the Commercial Production of Annual Statice (Limonium spp. Mill.) in Florida. Proc. Annual Meeting Florida State Hort. Soc. 86:399-404.

Yousef, Aml., Hala, R.M., Emam, and Saleh, S. 2011. Olive seedlings growth as affected by humic and amino acids, macro and trace elements applications. Agric. Biol. J. N. Am., 2(7): 1101-1107.

Zafar, M.S. 2007. Efficacy of various micronutrients on growth and flowering of Rosa hybrida cv. Kardinal. p. 2. MSc (Hons.) Thesis. University of Agriculture, Institute of Horticultural Sciences, Faisalabad, Pakistan.

Zaky, M.H., Zoah, E.L., and Ahmed, M.E. 2006. Effects of humic acids on growth and productivity of bean plants grown under plastic low tunnels and open field. Egypt. J. Appl. Sci., 21(4B): 582-596. 


\section{الملغص العري \\ درلسة الستجلبة نبلتات الستالتس لالمعاملة بحاهض الهيوميك \\ حنلن عز الين البراهم، حنان غالى هسن الفضالى، عالمم عبلس محمد النجار}

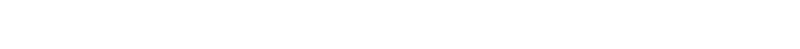

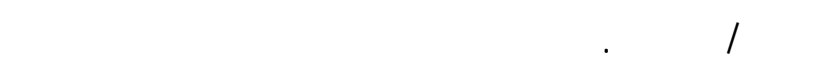

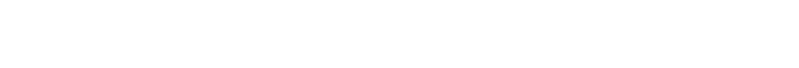

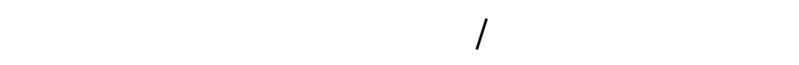

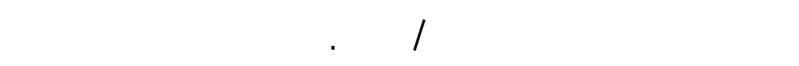

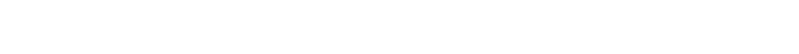

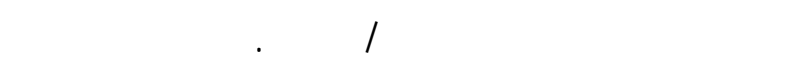

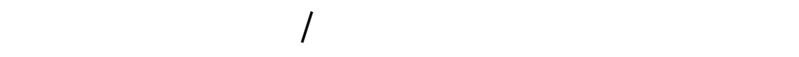
الجلف للزهيرات/حلمل زهرى. أما أعلى القيم المعنوي زهئة

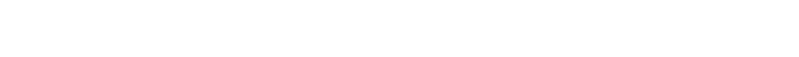

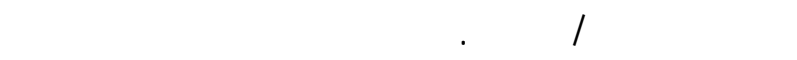
بحلمض الهيوميك على محتوى الاوراق مـ ن الكلوروفي لـ لـ والعناصر المعنية(النتروجين والفوس فور والبوتلنس يوميو)

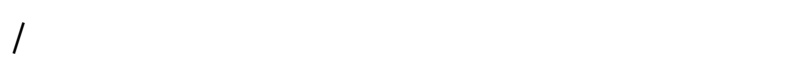
10 يوم أعلى أعلى القيم المعنوية لتلك الصفات.

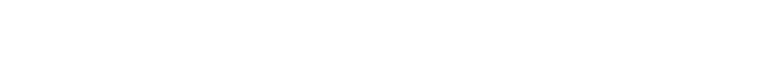

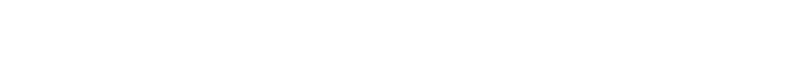

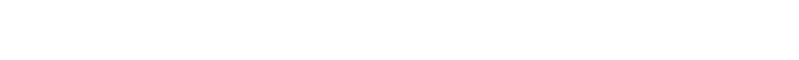
ومحتواها من العناصر المعنية مقارنة بنبانتا الكنت -رول.

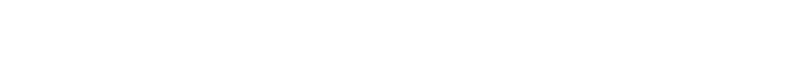
زياة المتصاص العناصر المعنية (النتروجين والفوس فور

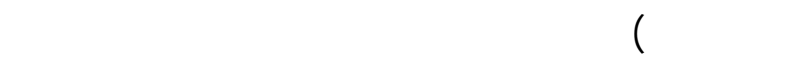

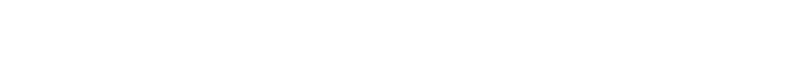

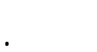

لجريت تجربة أصص على نباتنات المستانس Limonium

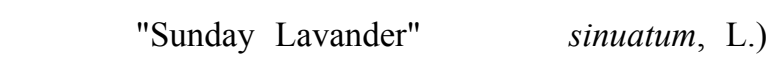

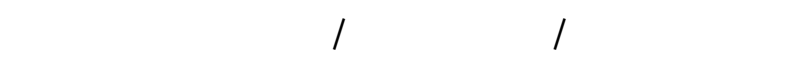

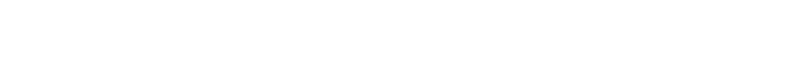

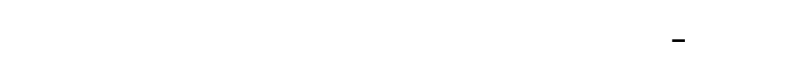

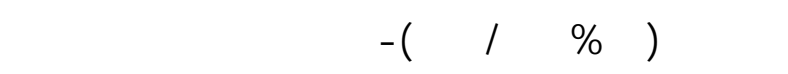

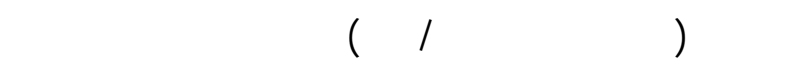

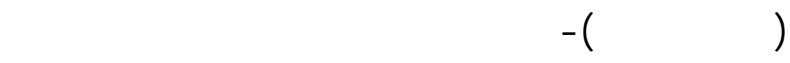

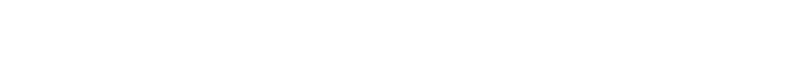

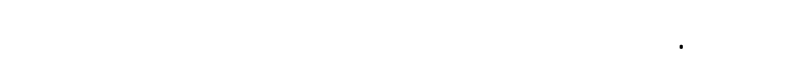

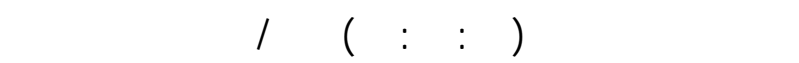

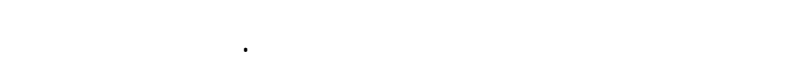

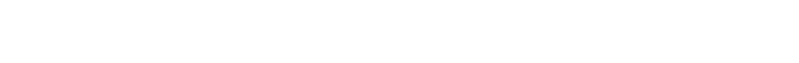

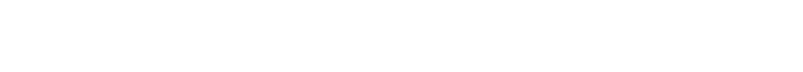

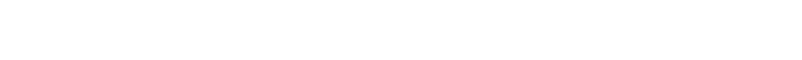
ومحتواها من العناصر المعنية مقارية بنباتتات الكنت -رول.

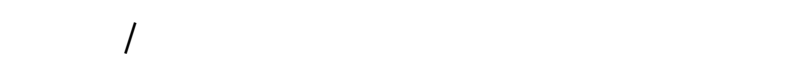

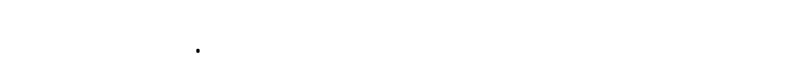

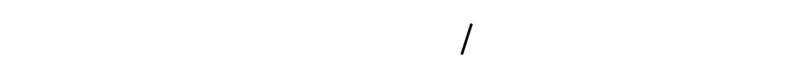
المعنوية لصفلت عدد الاوراق/ نبت والم سلحة الورقي مة المعال

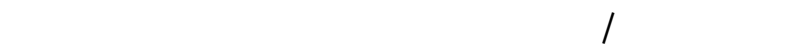
لللاوراق/نبلت.في حين أن أعلى القيم المعنوي ـة النط ـر

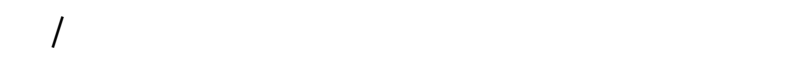

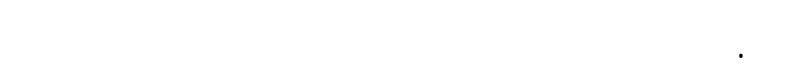
الطازج والجف لللاوراق والوزن الجلف للسق لوظظ ت 